\title{
PENYISIHAN AMONIAK DALAM UPAYA MENINGKATKAN KUALITAS AIR BAKU PDAM-IPA BOJONG RENGED DENGAN PROSES BIOFILTRASI MENGGUNAKAN MEDIA PLASTIK TIPE SARANG TAWON
}

\author{
${ }^{1}$ Wahyu Widayat, ${ }^{2}$ Suprihatin dan ${ }^{3}$ Arie Herlambang \\ ${ }_{1 \& 3}$ Peneliti pada Pusat Teknologi Lingkungan BPP Teknologi \\ 2 Staf pengajar pada Departemen Teknologi Industri Pertanian, IPB (Kampus Darmaga IPB)
}

\begin{abstract}
In big cities, the water quality of rivers used as the main raw water sources is getting worse and worse. That is caused by a lot of improper wastewater management systems, especially in industrial and settlement areas. As an example, the raw water of PDAM TKR Bojong Renged which is taken from Cisadane Rives contains Ammonia 3.8 $\mathrm{mg} / \mathrm{l}$ and it means that the content is not allowed to be used as the raw water for drinking water purpose. To cope with the problem, a bofiltration process can be used as one alternative to reduce Ammonia till the required standard quality. A honeycomb tube type made plastic was the media of biofilter reactor. Operational condition was varied with HRT (Hydrolysis Retention Time) between 1-4 hours and air supply between 0-30 $\mathrm{I} /$ minute. The best process condition was found at 2 hour-HRT and $20 \mathrm{l} /$ minute air supply and the Ammonia removal efficiency was about 65\%. The linear regression equation was $y_{a}=-91.19 x_{a}+77.12$, where $Y$ is for removal efficiency and the axis $X$ is for Ammonia loading.
\end{abstract}

Keywords: raw water quality, ammonia, biofiltration, honeycomb tube, removal efficiency,

\section{PENDAHULUAN}

\subsection{Latar Belakang Masalah}

Kualitas air sungai yang dipakai sebagai sumber air baku perusahaan air minum (PAM) semakin menurun seiring dengan peningkatan jumlah penduduk, sebagai akibatnya biaya produksi semakin mahal dan pada kondisi tertentu menyebabkan PAM tidak dapat lagi memberikan pelayanan yang baik kepada masyarakat karena kualitas air olahan buruk. PDAM Tirta Kerta Raharja (TKR) kabupaten Tangerang melakukan pemantauan kualitas air baku pada instalasi pangolahan air (IPA) wilayah Bojong Renged, Tangerang pada bulan September 2000. Kualitas air baku (sungai Cisadane) sudah tidak layak lagi digunakan sebagai sumber air baku PAM, karena salah satu parameter yaitu amoniak tidak memenuhi kriteria mutu air Golongan I (11). Konsentrasi amoniak antara 0,06-1,09 mg/l, kondisi tersebut menjadi dua kali lipat bahkan lebih pada musim kemarau. Bulan agustus 2009 konsentrasi amoniak $\left(\mathrm{NH}_{4-}\right.$ N) mencapai $3,8 \mathrm{mg} / \mathrm{l}$ sehingga IPA Bojong Renged menghentikan proses pengolahan untuk sementara waktu, karena instalasi pengolahan yang ada sudah tidak mampu lagi mengolah dengan kondisi air baku seperti tersebut diatas.

PAM di Indonesia menggunakan senyawa klor (gas klor atau kalsium hipoklorit) untuk mereduksi mikroorganisma (desinfeksi). Selama proses desinfeksi gas khlor juga bereaksi dengan senyawa organik, amoniak, logam besi dan mangan. Meningkatnya konsentrasi zat pencemar tersebut mengakibatkan kebutuhan khlor semakin banyak, akibatnya muncul hasil samping dari proses khlorinasi, yaitu terbentuknya senyawa trihalometan (THM) dan diikuti kenaikan konsentrasi senyawa halogen organik lainnya. Amoniak dalam air baku bereaksi dengan klor membentuk kloramin dengan daya desinfeksi lebih lemah, sehingga konsumsi khlor menjadi lebih besar, akibatnya biaya operasional meningkat.

Upaya PAM meningkatkan kualitas air olahan adalah dengan menerapkan pengolahan lanjutan (advanced treatment), yaitu menggunakan karbon aktif bubuk di bak pengendap akhir atau granular pada filter karbon aktif. Cara ini mampu meningkatkan kualitas air olahan, namun membutuhkan biaya yang tidak sedikit dan karbon aktif yang telah dipakai tidak dapat digunakan lagi (limbah padat). PAM sampai saat ini belum memungkinkan membuat instalasi baru yang menyesuaikan kualitas air baku, salah satu cara yang perlu dipertimbangkan saat ini adalah dengan melakukan pengolahan awal (pretreatment) menggunakan proses biologis untuk meningkatkan kualitas air baku dengan penerapan proses biofiltrasi menggunakan media plastik tipe sarang tawon. 


\subsection{Tujuan Penelitian}

Tujuan penelitian ini adalah mengkaji karakteristik dan membuat rekomendasi disain reaktor biofilter dengan media plastik tipe sarang tawon untuk penyisihan konsentrasi senyawa amoniak dalam air baku PAM.

\subsection{Ruang Lingkup}

Lingkup penelitian ini adalah: penerapan reaktor biofilter (bioreaktor), pembiakan mikroorganisma, pelaksanaan penelitian, analisa laboratorium dan perhitungan efisiensi penyisihan amoniak.

\section{TINJAUAN PUSTAKA}

\subsection{Senyawa Amoniak}

Amoniak $\left(\mathrm{NH}_{3}\right)$ di dalam air adalah senyawa nitrogen amoniak dalam bentuk $\mathrm{NH}_{4}{ }^{+}$ disebut dengan amonium. Amoniak dalam air sungai berasal dari air seni, tinja dan hasil penguraian secara mikrobiologis terhadap zat organik yang berasal dari air alam, air buangan industri dan limbah domestik. Keberadaan amoniak tergantung pada beberapa faktor yaitu sumber amoniak, adanya tanaman air yang menyerap amoniak sebagai nutrien, konsentrasi oksigen terlarut dan temperatur ${ }^{(1)}$.

Di musim panas konsentrasi senyawa ini bisa sangat rendah, hal ini disebabkan amoniak diserap oleh tumbuhan pada saat asimilasi, selain itu konsentrasi amoniak dapat juga dipengaruhi oleh suhu air, dimana suhu yang tinggi dapat mempengaruhi proses nitrifikasi. Kondisi pada suhu yang rendah yaitu musim dingin, pertumbuhan bakteri berkurang sehingga proses nitrifikasi berjalan lambat menyebabkan konsentrasi amoniak tinggi. Kadar amoniak yang tinggi pada air sungai menimbulkan pencemaran dan mengganggu siklus kehidupan perairan. Keberadaan amoniak dalam air minum menimbulkan rasa tidak enak dan mengganggu kesehatan sehingga kadar $\mathrm{NH}_{3}$ harus nol. Konsentrasi amoniak dalam air sungai sebagai air baku air minum harus di bawah $1 \mathrm{mg} / \mathrm{l}$.

Nitrogen amoniak berada dalam air sebagai amonium $\left(\mathrm{NH}_{4}^{+}\right)$, yaitu berdasarkan reaksi kesetimbangan sebagai berikut ${ }^{(1)}$ :

$$
\mathrm{NH}_{3}+\mathrm{H}_{2} \mathrm{O} \rightarrow \mathrm{NH}_{4}^{+}+\mathrm{OH}^{-}
$$

Keberadaan amoniak tersebut dapat menyebabkan kondisi toksik bagi kehidupan perairan. Kadar amoniak bebas dalam air meningkat sejalan dengan meningkatnya $\mathrm{pH}$ dan suhu. Kehidupan air terpengaruh oleh amoniak pada konsentrasi $1 \mathrm{mg} / \mathrm{l}$ dan dapat menyebabkan mati lemas karena dapat mengurangi konsentrasi oksigen dalam air.

PAM pada umumnya menggunakan senyawa khlor pada proses desinfeksi dan untuk mengoksidasi senyawa organik. Keberadaan senyawa amoniak dalam air baku PAM dapat mengurangi efektifitas khlorin untuk mengoksidasi senyawa organik dan membunuh bakteri. Senyawa klor yang diinjeksikan ke dalam air akan mengalami hidrolisa membentuk asam hipoklorit $(\mathrm{HOCl})$. Asam hipoklorit dapat bereaksi dengan amoniak dalam air membentuk khloramin, dimana khloramin ini kurang efektif membunuh bakteri.

Senyawa amoniak dalam air dapat diolah secara mikrobiologis oleh bakteri autotropik dan heterotropik melalui proses nitrifikasi hingga membentuk nitrit dan nitrat. Proses nitrifikasi ini berlangsung dalam kondisi aerobik, sehingga diperlukan penambahan oksigen melalui aerasi(2).

\subsection{Proses Nitrifikasi}

Sebagian besar amoniak di alam akan dioksidasi menjadi bentuk nitrit $\left(\mathrm{NO}_{2}{ }^{-}\right)$dan kemudian menjadi nitrat $\left(\mathrm{NO}_{3}{ }^{-}\right)$yang dilakukan oleh dua macam bakteri autotrop dalam proses yang disebut nitrifikasi. Amoniak sangat berguna bagi tumbuhan dan mikroorganisma untuk asimilasi menjadi sel baru yang memberikan lebih banyak nitrogen organik. Senyawa nitrat dan amoniak dalam air digunakan oleh tumbuhan dan mikroorganisme dalam proses biosintesis (asimilasi) untuk membentuk sel baru yang akan menghasilkan nitrogen organik(2).

$$
\begin{aligned}
& 4 \mathrm{NO}_{3}^{\circ}+8 \mathrm{H}_{2} \mathrm{O} \rightarrow 4 \mathrm{NH}_{3}+8 \mathrm{O}_{2}+4 \mathrm{OH}^{-} \\
& \mathrm{NH}_{3}+\mathrm{CO}_{2} \underset{\text { tumbuhan hijau }}{\text { cahaya matahari }} \rightarrow \text { protein }
\end{aligned}
$$

Peran senyawa nitrogen dalam proses pertumbuhan diketahui dari bentuk serta perubahannya yang terjadi di alam dalam suatu siklus yang disebut siklus nitrogen. Berikut ini adalah gambar siklus nitrogen yang terjadi di lingkungan perairan(7).

Senyawa nitrit merupakan bahan peralihan yang terjadi pada siklus biologi. Senyawa ini dihasilkan dari suatu proses oksidasi biokimia amonium, tetapi sifatnya tidak stabil karena pada kondisi aerobik, selama nitrit terbentuk dengan cepat nitrit dioksidasi menjadi nitrat oleh bakteri nitrobacter. 


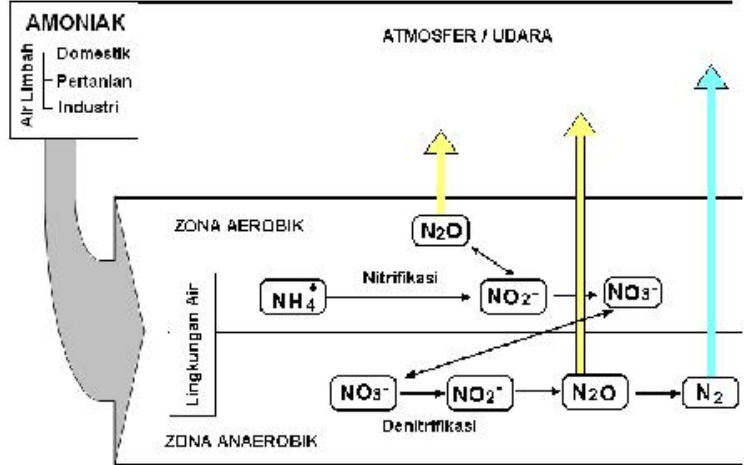

Gambar 1. Siklus Nitrogen

Sedangkan pada kondisi anaerobik, nitrat dapat direduksi menjadi nitrit yang selanjutnya hasil reduksi tersebut dilepaskan sebagai gas nitrogen. Nitrit yang ditemui pada air minum dapat berasal dari bahan inhibitor korosi yang dipakai di pabrik yang mendapatkan air dari sistem distribusi perusahaan air minum. Konsentrasi nitrit di dalam air permukaan sangat rendah (dalam $\mu \mathrm{g} / \mathrm{l}$ ), tetapi konsentrasi yang tinggi ditemukan pada limbah dan rawa dimana kondisi anaerobik sering dijumpai(4).

Proses nitrifikasi didefinisikan sebagai konversi nitrogen ammonium $\left(\mathrm{N}-\mathrm{NH}_{4}\right)$ menjadi nitrit $\left(\mathrm{N}-\mathrm{NO}_{2}\right)$ yang kemudian menjadi nitrat $(\mathrm{N}-$ $\mathrm{NO}_{3}$ ) yang dilakukan oleh bakteri autotropik dan heterotropik. Proses nitrifikasi ini dibagi dalam dua tahap yaitu :

\section{a. Tahap nitritasi}

Tahap ini merupakan tahap oksidasi ion amonium $\left(\mathrm{NH}_{4}{ }^{+}\right)$menjadi ion nitrit $\left(\mathrm{NO}_{2}^{-}\right)$yang dilaksanakan oleh bakteri nitrosomonas menurut reaksi berikut :

$2 \mathrm{NH}_{4}^{+}+3 \mathrm{O}_{2}+2 \mathrm{OH}^{-} \rightarrow 2 \mathrm{NO}_{2}^{-}+2 \mathrm{H}^{+}+4 \mathrm{H}_{2} \mathrm{O}+59,4 \mathrm{Kcal}$ Nitrosomonas

Reaksi tersebut memerlukan 3,43 gram $\mathrm{O}_{2}$ untuk mengoksidasi 1 gram nitrogen menjadi nitrit.

\section{b. Tahap nitrasi}

Tahap nitrasi adalah oksidasi ion nitrit $\left(\mathrm{NO}_{2}\right)$ menjadi ion nitrat $\left(\mathrm{NO}_{3}^{-}\right)$yang dilaksanakan oleh bakteri nitrobacter dengan reaksi berikut :

$$
\begin{gathered}
\mathrm{NO}_{2}{ }^{-}+1 / 2 \mathrm{O}_{2} \rightarrow \mathrm{NO}_{3}{ }^{-}+18 \mathrm{Kcal} \\
\text { Nitrobacter }
\end{gathered}
$$

Reaksi tersebut memerlukan 1,14 gr $\mathrm{O}_{2}$ untuk mengoksidasi $1 \mathrm{gr}$ nitrogen menjadi nitrat. Secara keseluruhan proses nitrifikasi dapat dilihat dari persamaan berikut ${ }^{(3)}$ :

$$
\mathrm{NH}_{4}^{+}+2 \mathrm{O}_{2} \rightarrow \mathrm{NO}_{3}^{-}+2 \mathrm{H}^{+}+\mathrm{H}_{2} \mathrm{O}
$$

Kedua reaksi diatas disebut dengan reaksi eksotermik (reaksi yang menghasilkan energi). Apabila kedua jenis bakteri tersebut ada, baik di tanah maupun di perairan, maka konsentrasi nitrit akan menjadi berkurang karena nitrit dibentuk oleh bakteri nitrosomonas yang akan dioksidasi oleh bakteri nitrobacter menjadi nitrat. Kedua bakteri ini dikenal sebagai bakteri autotropik, yaitu bakteri yang dapat mensuplai karbon dan nitrogen dari bahan-bahan anorganik dengan sendirinya. Bakteri ini menggunakan energi dari proses nitrifikasi untuk membentuk sel sintesa yang baru. Sedangkan bakteri heterotropik merupakan bakteri yang membutuhkan bahanbahan organik untuk membangun protoplasma. Walaupun bakteri nitrifikasi autotropik keberadaannya di alam lebih banyak, proses nitrifikasi dapat juga dilakukan oleh bakteri jenis heterotropik (Arthobacter) dan jamur (Aspergillus) (1).

$\mathrm{Di}$ dalam proses pengolahan secara aerobik senyawa $\mathrm{N}-\mathrm{NH}_{4}$ yang ada di perairan dioksidasi menjadi nitrat. Mengingat kebutuhan $\mathrm{O}_{2}$ yang cukup besar, maka terjadi penurunan oksigen di dalam perairan tersebut sehingga terjadi kondisi septik. Upaya memenuhi kebutuhan $\mathrm{O}_{2}$ tersebut, dapat dipenuhi dengan cara memperbesar transfer $\mathrm{O}_{2}$ ke dalam instalasi pengolahan. Transfer $\mathrm{O}_{2}$ dapat dilakukan dengan cara menginjeksikan udara ke dalam reaktor dan memperluas kontak antara gelembung udara dengan air dengan cara memasang difuser yang lebih halus dan merata(8).

\subsection{Faktor Pengontrol Nitrifikasi}

Faktor pengontrol proses nitrifikasi dalam proses pengolahan air antara lain adalah ${ }^{(1)}$ :

\section{A. Oksigen Terlarut (Dissolved Oxigen)}

Proses nitrifikasi terjadi dalam kondisi aerob, sehingga keberadaan oksigen sangat penting dalam proses ini. Proses nitrifikasi berjalan dengan baik jika $\mathrm{DO}>1 \mathrm{mg} / \mathrm{l}$.

\section{B. Suhu}

Pertumbuhan bakteri nitrifikasi terjadi pada suhu antara $8-30^{\circ} \mathrm{C}$, dengan suhu optimum sekitar $30^{\circ} \mathrm{C}$

C. $\mathrm{pH}$

$\mathrm{pH}$ optimum pertumbuhan nitrosomonas dan nitrobacter antara 7,5-8,5 dan pada $\mathrm{pH}$ di bawah 6 pertumbuhan terhambat.

\subsection{Media Biakan Tipe Sarang Tawon}

Faktor yang mempengaruhi pertumbuhan mikroorganisma pada media biakan (penyangga) adalah kecepatan aliran bentuk, jenis, dan jenis 
konfigurasi media. Media biakan yang baik harus mempunyai beberapa syarat antara lain(2) :

- Luas permukaan besar

- Tidak bersifat racun (toksik) terhadap mikroorganisma

- Sifat fisika dan kimia stabil

- Celah difusi udara dapat dilewati oleh lapisan biofilm yang mati dan terlepas.

Media yang digunakan dapat berupa kerikil, batu pecah (split), media plastik (polivinil khlorida), dan partikel karbon aktif dan lainnya. Media yang sering digunakan pada proses biologis khususnya biofiter adalah media plastik tipe sarang tawon. Modul media tipe sarang tawon dapat dilihat pada Gambar 2. Kelebihan media plastik tipe sarang tawon ini antara lain :

- Luas permukaan per satuan volume (luas spesifik) besar antara $85-226 \mathrm{~m}^{2} / \mathrm{m}^{3}$.

- Volume rongga besar ( $\pm 95 \%$ ) sehingga resiko kebuntuan kecil.

- Ringan, mudah diaplikasikan dan dapat disusun sampai ketinggian $10 \mathrm{~m}$.

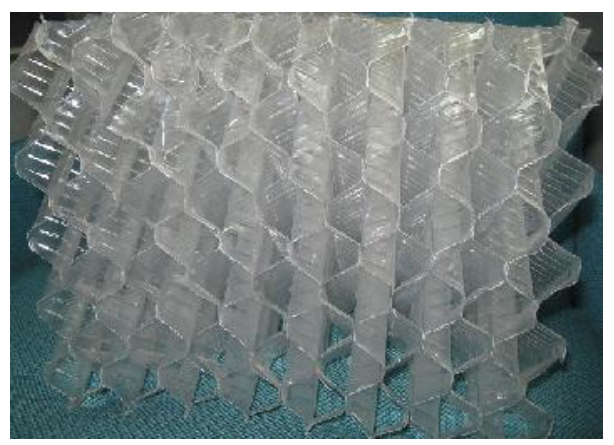

Gambar 2. Media biofilter tipe sarang tawon

Di dalam reaktor biofilter, mikroorganisma tumbuh melapisi keseluruhan permukaan media dan pada saat beroperasi air mengalir melalui celah-celah media kemudian kontak dengan lapisan masa mikroba (biofilm). Proses awal pertumbuhan mikroba dan pembentukan lapisan film pada media membutuhkan waktu 14 sampai 60 hari, yang dikenal dengan proses pematangan. Pada awalnya tingkat efisiensi penyisihan sangat rendah yang kemudian akan mengalami peningkatan setelah terbentuknya lapisan film biologis ${ }^{(4)}$. Mekanisme perpindahan masa yang terjadi pada permukaan media dinyatakan sebagai berikut(2) :

- Difusi substansi air (mengandung polutan) ke dalam masa mikroba yang melapisi media.

- Reaksi peruraian bahan organik maupun anorganik oleh mikroba.

- Difusi hasil penguraian ke luar dari badan air yang mengandung polutan.

\subsection{Mekanisme Penyisihan Amoniak}

Lapisan biomasa atau biofilm didefinisikan sebagai lapisan tipis sel mikroba yang berkaitan dengan penguraian zat organik yang melekat pada suatu permukaan media. Kecepatan pertumbuhan lapisan biofilm pada permukaan bertambah akibat perkembangbiakan dan adsorpsi yang terus berlanjut sehingga terjadi proses akumulasi lapisan biomassa yang berbentuk lapisan lendir (slime). Pertumbuhan mikroorganisme terus berlangsung pada slime yang sudah terbentuk sehingga ketebalan slime bertambah. Difusi makanan dan oksigen terus berlangsung sampai tercapai ketebalan maksimum sehingga pada kondisi ini difusi makanan dan oksigen ini tidak mampu lagi mencapai permukaan padatan yang akibatnya lapisan biomassa ini terbagi menjadi dua kapling (zona) yaitu zona aerob dan zona anaerob. Pada kondisi ini mulai terjadi akumulasi biomassa dan secara alami juga terjadi pengelupasan lapisan biomassa yang sudah mati dan selanjutnya segera terbentuk koloni mikroorganisma yang baru sehingga pembentukan biofilm terus berlangsung dan mengalami regenerasi(6).

Efisiensi penyisihan amoniak pada proses biofiltrasi oleh lapisan biomasa dapat mencapai maksimum apabila lapisan tipis di bagian luar lapisan biomassa telah mencapai ketebalan maksimum untuk kondisi aerobik. Lapisan terluar media penyangga adalah lapisan tipis zona aerobik, dimana senyawa amoniak dioksidasi dan diubah ke dalam bentuk nitrit. Sebagian senyawa nitrit ada yang diubah menjadi gas dinitrogen oksida $\left(\mathrm{N}_{2} \mathrm{O}\right)$ dan ada yang diubah menjadi nitrat. Proses yang terjadi tersebut dinamakan proses nitrifikasi ${ }^{(7)}$.

Ketebalan lapisan biomasa tergantung pada karakteristik dari air baku yang diolah. Ketebalan lapisan aerobik antara 0,05-0,1 mm dan ketebalan total lapisan biomassa 0,1-2 mm. Sejalan dengan waktu proses penguraian, lapisan biofilm yang tumbuh pada media penyangga bertambah tebal sehingga menyebabkan oksigen tidak dapat masuk ke dalam lapisan biofilm bagian dalam dan mengakibatkan terbentuknya zona anaerobik. Pada zona anaerobik ini, senyawa nitrat yang terbentuk diubah ke dalam bentuk nitrit kemudian dilepas menjadi gas nitrogen $\left(\mathrm{N}_{2}\right)$. Mekanisme ini dinamakan proses denitrifikasi ${ }^{(6)}$.

\section{METODE PENELITIAN}

\subsection{Alat dan Bahan}

\subsubsection{Air Baku}

Air yang dipakai sebagai bahan penelitian adalah air baku PDAM TKR wilayah IPA Bojong 
Renged, yaitu air sungai Cisadane. Air baku diambil dari pipa utama (intake) sebelum masuk instalasi pengolahan air PDAM.

\subsubsection{Mikroorganisma}

Mikroorganisma diperoleh dari air baku PDAM TKR-IPA Bojong Renged, selanjutnya dilakukan pembiakan (seeding) mikroorganisma secara alami, yaitu dengan cara mengalirkan air baku secara kontinyu ke dalam reaktor melalui media biofilter sampai terbentuk lapisan biofilm yang melekat pada media.

\subsubsection{Reaktor Biofilter}

Reaktor biofilter dibuat dari bahan FRP dengan dimensi panjang $180 \mathrm{~cm}$, lebar $100 \mathrm{~cm}$ dan tinggi $160 \mathrm{~cm}$. Total volume reaktor 2880 liter, sedangkan volume kerja adalah 2520 liter. Media biofilter terbuat dari plastik tipe sarang tawon dengan ukuran modul $30 \times 30 \times 25 \mathrm{~cm}$, luas permukaan $226 \mathrm{~m}^{2} / \mathrm{m}^{3}$, porositas $98 \%$ dan total volume media yang digunakan 0,855 $\mathrm{m}^{3}$. Spesifikasi reaktor biofilter secara lengkap dapat dilihat pada tabel berikut:

Tabel 1. Spesifikasi reaktor biofilter

\begin{tabular}{|c|c|c|c|}
\hline No & Uraian & Keterangan & Jumlah \\
\hline 1 & $\begin{array}{l}\text { Dimensi reaktor: } \\
\text { Panjang } \\
\text { Lebar } \\
\text { Tinggi } \\
\text { Volume reaktor } \\
\text { Volume efektif } \\
\text { Bahan }\end{array}$ & $\begin{array}{l}180 \mathrm{Cm} \\
100 \mathrm{Cm} \\
160 \mathrm{Cm} \\
2880 \text { liter } \\
2520 \text { liter } \\
\text { FRP }\end{array}$ & 1 unit \\
\hline 2 & $\begin{array}{l}\text { Media biofilter : } \\
\text { Bahan / warna } \\
\text { Tipe } \\
\text { Ukuran lubang } \\
\text { Ketebalan sheet } \\
\text { Ukuran modul } \\
\text { Luas permukaan } \\
\text { Berat spesifik } \\
\text { Porositas media }\end{array}$ & $\begin{array}{l}\text { Plastik/ transparan } \\
\text { Sarang tawon } \\
(2 \times 2) \mathrm{cm} \\
0.5 \mathrm{~mm} \\
(30 \times 30 \times 25) \mathrm{cm} \\
\pm 226 \mathrm{~m}^{2} / \mathrm{m}^{3} \\
30-35 \mathrm{~kg} / \mathrm{m}^{3} \\
98 \%\end{array}$ & $0,855 \mathrm{~m}^{3}$ \\
\hline 3 & $\begin{array}{l}\text { Flowmeter } \\
\text { Kapasitas } \\
\text { Diameter in/out }\end{array}$ & $\begin{array}{l}0-26 \text { liter/menit } \\
1 / 2 \text { inch }\end{array}$ & 2 unit \\
\hline 4 & $\begin{array}{l}\text { Blower udara } \\
\text { Tipe } \\
\text { daya } \\
\text { Kapasitas }\end{array}$ & $\begin{array}{l}\text { Hiblow } 30, \\
60 \mathrm{~W} / 220 \mathrm{~V} \\
30 \text { liter/ menit }\end{array}$ & 2 unit \\
\hline 5 & $\begin{array}{l}\text { Difuser (diffucer) } \\
\text { Tipe } \\
\text { diameter } \\
\text { Kapasitas }\end{array}$ & $\begin{array}{l}\text { Gelembung (Bubble) } \\
7.5 \mathrm{Cm} \\
20 \text { liter/menit }\end{array}$ & 4 unit \\
\hline 6 & $\begin{array}{l}\text { Pompa sirkulasi } \\
\text { Tipe } \\
\text { Kapasitas } \\
\text { Daya }\end{array}$ & $\begin{array}{l}\text { Celup (submercible) } \\
2-15 \text { liter/menit } \\
100 \mathrm{~W} ; 220 \mathrm{~V}\end{array}$ & 1 unit \\
\hline 7 & $\begin{array}{l}\text { Perpipaan } \\
\text { Kelistrikan }\end{array}$ & $\begin{array}{l}\text { Instalasi } 1 / 2 \text { " }-4 " \\
110 \mathrm{~W}, 220 \mathrm{~V}\end{array}$ & 1 paket \\
\hline
\end{tabular}

Reaktor biofilter dibagi menjadi 3 ruang, yaitu pengendap awal, media dan pengendap akhir. Lubang masuk air baku (inlet) dan lubang air produk (outlet) yang terletak pada kedua sisi reaktor. Lumpur yang terendapkan dapat dikeluarkan melalui ruang lumpur pada bagian bawah reaktor. Rancangan reaktor biofilter dapat dilihat pada Gambar 3.

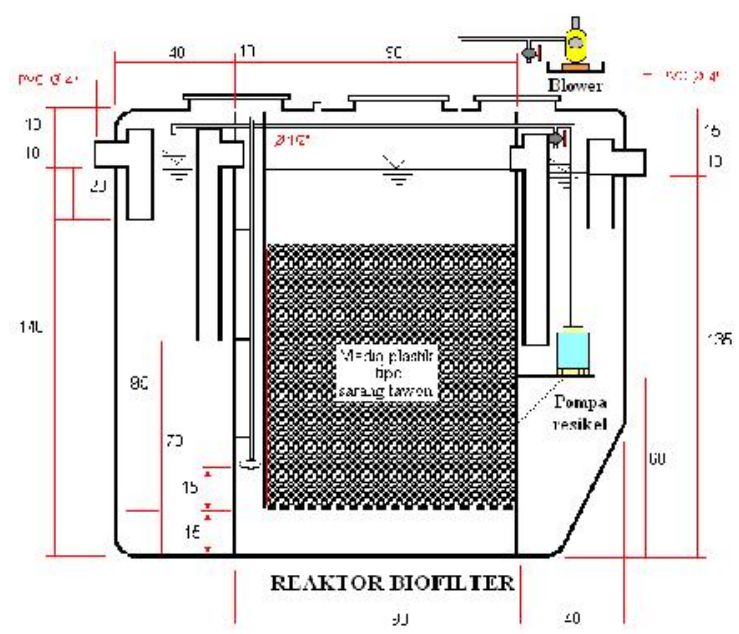

Gambar 3. Rancangan reaktor biofilter.

\subsection{Rancangan Penelitian}

Penelitian dilakukan dengan eksperimen, dimana air umpan sebagai bahan penelitian diambil dari air baku PDAM TKR wilayah IPA Bojong Renget dan mikroorganisma yang dipakai diambil dari air baku dan ditumbuhkan secara alami pada media penyangga yang terbuat dari plastik berbentuk sarang tawon.

Pelaksanaan penelitian mencakup kegiatan lapangan dan laboratorium. Kegiatan lapangan yaitu pengambilan sampel, pengukuran $\mathrm{pH}$, temperatur dan oksigen terlarut yang dilakukan setiap hari pada jam 08.00-09.00 WIB (disesuaikan dengan WTH) baik air umpan (masuk) maupun air hasil olahan (keluar). Kegiatan laboratorium merupakan kegiatan analisa sampel terhadap konsentrasi zat organik (saat seeding), amoniak, nitrat, dan nitrit.

\subsubsection{Metoda Pengumpulan Data}

Data sekunder diperoleh dari studi pustaka, laporan swapantau harian dan laporan bulanan bagian produksi PDAM TKR wilayah IPA Bojong Renget. Data primer diperoleh dari pengukuran langsung dari lapang dan analisa laboratorium. Data yang diambil dari pegukuran langsung di lapang (insitu) antara lain suhu, $\mathrm{pH}$ dan DO, sedangkan data yang diperoleh dari laboratorium adalah konsentrasi organik, amoniak, nitrit dan nitrat.

\subsubsection{Variabel}

Variabel dalam penelitian ini adalah: 
a Variabel bebas yaitu perlakuan waktu tinggal hidrolis (WTH) dan suplai udara.

b Variabel terikat yaitu pembebanan senyawa amoniak, nitrit dan nitrat.

Penelitian dilakukan pada suhu kamar dengan variasi WTH seperti yang ditunjukkan pada Tabel 2. Selanjutnya penelitian dilanjutkan dengan perlakuan variasi suplai udara $0,10,20$ dan 30 liter/menit pada WTH terpilih.

Tabel 2. Debit air baku sesuai dengan WTH

\begin{tabular}{|c|c|c|}
\hline No & (WTH) Jam & Debit air (liter/menit) \\
\hline 1 & 1 & 42 \\
\hline 2 & 2 & 21 \\
\hline 3 & 3 & 14 \\
\hline 4 & 4 & 10.5 \\
\hline
\end{tabular}

\subsubsection{Metoda Analisis Data}

Data hasil penelitian dianalisis menggunakan metoda deskriptif dengan tabel, grafik dan narasi yang menggambarkan keseluruhan hasil perlakuan dalam penelitian. Langkah selanjutnya dari penelitian ini adalah analisis data, perhitungan efisiensi proses, beban proses dan pembuatan rekomendasi disain reaktor biofilter.

\subsubsection{Analisis Data}

Data dalam penelitian ini adalah data primer yang diperoleh dari pengukuran langsung di laboratorium. Data yang telah diperoleh pada tahap penelitian diolah dan disajikan dalam bentuk tabel dan grafik, serta dianalisa secara komprenhensif sesuai dengan teori yang ada. Rekomendasi disain reaktor biofilter digunakan untuk mendukung strategi-strategi dan peluang aplikasi hasil penelitian.

\subsubsection{Perhitungan Efisiensi Proses}

Perhitungan penyisihan kandungan zat polutan (amoniak) didasarkan atas perbandingan pengurangan konsentrasi zat pada titik masuk dan keluar terhadap konsentrasi zat di titik masuk. Efisiensi proses biofiltrasi dapat dilakukan dengan menggunakan persamaan berikut (8) :

$$
\text { Eff-C }=\frac{C_{\text {in }}-C_{\text {out }}}{C_{\text {in }}} \times 100 \%
$$

dimana;

Eff-C = Persentase penyisihan konsentrasi zat (\%)

$\mathrm{C}_{\text {in }}=$ Konsentrasi zat pada titik masuk (mg/l)

$\mathrm{C}_{\text {out }}=$ Konsentrasi zat pada titik keluar (mg/)

\subsubsection{Perhitungan Laju Pembebanan}

Laju pembebanan zat didefinisikan sebagai jumlah senyawa zat yang terdapat dalam air yang diuraikan oleh mikroorganisma di dalam bioreaktor per unit satuan luas permukaan media biofilter per hari. Laju beban ini digunakan untuk mengetahui jumlah total beban zat di dalam air yang akan diolah dalam biofilter dan dapat dihitung dengan persamaan:

$$
L=\frac{a \times C_{\text {in }}}{A_{m}}
$$

$$
\begin{aligned}
& \text { dimana; } \\
& L=\text { Laju pembebanan zat }\left(\mathrm{g} / \mathrm{m}^{2} \cdot\right. \text { hari) } \\
& Q=\text { Debit air yang diolah }\left(\mathrm{m}^{3} /\right. \text { hari) } \\
& C_{\text {in }}=\text { Konsentrasi zat pada titik masuk }\left(\mathrm{g} / \mathrm{m}^{3}\right) \\
& A_{\mathbf{m}}=\text { Luas permukaan media }\left(\mathrm{m}^{2}\right)
\end{aligned}
$$

\subsection{Batasan Penelitian}

Penelitian dibatasi oleh variabel dan parameter konsentrasi zat . Variabel bebas yang ditetapkan adalah waktu tinggal hidrolis (WTH) antara 1-4 jam dan suplai udara antara 0-30 liter/menit. Variabel terikat yaitu pembebanan (loading) amoniak dan parameter lainnya mengikuti kualitas air baku saat pelaksanaan penelitian. Parameter yang dianalisa adalah konsentrasi zat organik sebagai $\mathrm{KMnO}_{4}$ pada saat seeding dan amoniak sebagai $\mathrm{NH}_{4}-\mathrm{N}$. Parameter terkait yang diukur dalam penelitian ini adalah konsentrasi nitrat sebagai $\mathrm{NO}_{3}-\mathrm{N}$, nitrit sebagai $\mathrm{NO}_{2}-\mathrm{N}$, DO, suhu dan $\mathrm{pH}$.

Mikroba yang digunakan berasal dari air baku (tidak mengasimilasi dari luar sistem), dan identifikasi mikroba dibatasi pada jenis mikroba yang diindikasikan sebagai pengurai amoniak.

\subsection{Pelaksanaan Penelitian}

Tahapan pelaksanaan penelitian yaitu persiapan alat/bahan, pembiakan mikroba, pelaksanaan percobaan, pengambilan dan analisa sampel (inlet dan outlet), analisis data, penyusunan laporan serta membuat rekomendasi. Pelaksanaan penelitian dapat dilihat pada Gambar 4.

Reaktor biofilter ditempatkan sekitar pipa utama (intake) air baku PDAM TKR wilayah IPA Bojong Renget. Air baku diambil dengan cara tapping pada pipa utama selanjutnya dialirkan ke dalam reaktor melalui flowmeter untuk diatur laju alirnya. Laju alir air baku diukur menggunakan dua buah flowmeter yang bekerja sesuai WTH dengan skala 0-26 liter/menit. Pengaturan laju alir dilakukan dengan pengaturan putaran keran 
sampai menunjukkan debit sesuai dengan WTH, seperti ditunjukkan pada Tabel 2. Langkah selanjutnya air baku dimasukkan ke dalam reaktor biofilter dengan arah dari bawah ke atas (up flow) melalui media biofilter.

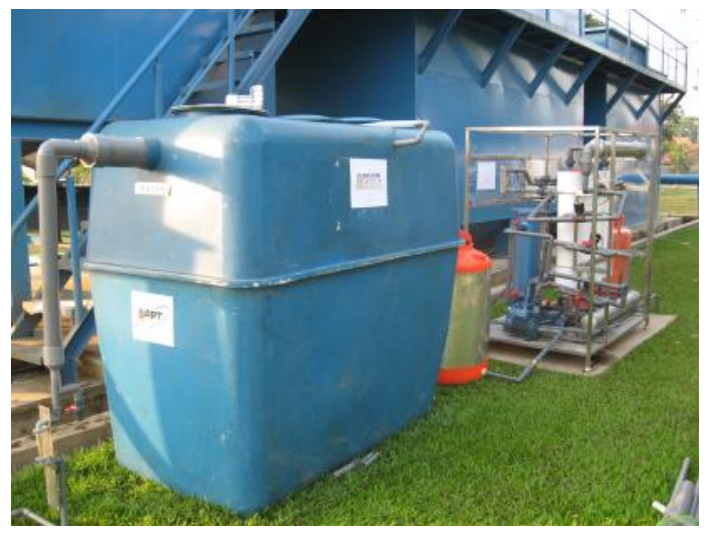

Gambar 4. Pelaksanaan penelitian

Udara di dalam reaktor disuplai oleh dua buah blower dengan daya $60 \mathrm{~W} / 220 \mathrm{~V}$ yang bekerja sesuai dengan kebutuhan variasi suplai udara. Suplai udara diatur dengan pengaturan putaran keran dan diukur menggunakan flowmeter udara. Pendistribusian udara menggunakan difuser dengan diameter $7,5 \mathrm{~cm}$ sebanyak 4 buah dengan kapasitas maksimal masing-masing 20 liter/menit. Antisipasi fluktuasi pembebanan serta pembebanan mendadak (shock loading) dilakukan dengan sirkulasi menggunakan pompa celup (submersible pump) dengan debit seperempat laju alir air baku.

Sampel air baku dan air olahan diambil sesuai dengan rancangan percobaan dan dilakukan analisa laboratorium. Alur proses penelitian dapat dilihat pada gambar berikut:

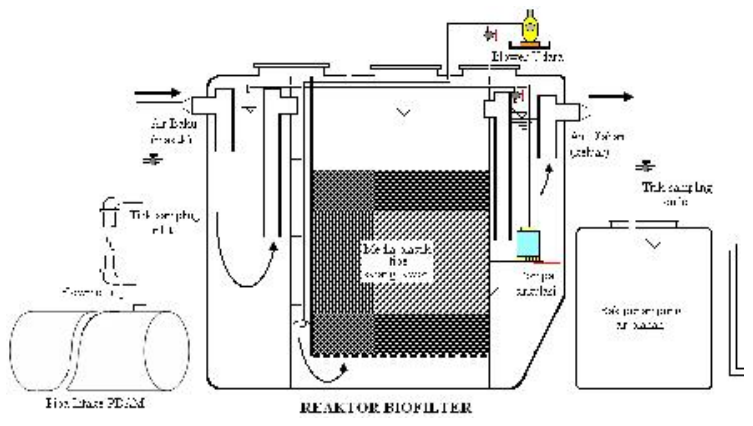

Gambar 5. Alur proses penelitian.

\section{HASIL DAN PEMBAHASAN}

\subsection{Identifikasi Air Baku PAM}

Kualitas air baku PDAM TKR Kabupaten Tangerang yaitu sungai Cisadane, khususnya pada intake instalasi pengolahan air wilayah
Bojong Renged yang tidak memenuhi kriteria mutu air sebagai air baku PAM, karena salah satu parameter yaitu amoniak $\left(\mathrm{NH}_{4}-\mathrm{N}\right)$ rata-rata mencapai $1.2 \mathrm{mg} / \mathrm{l}$. Berdasarkan kriteria mutu air golongan I, yaitu air yang dapat digunakan sebagai air baku air minum, konsentrasi maksimum amoniak ( $\left.\mathrm{NH}_{4}-\mathrm{N}\right)$ 0,5 mg/l (11).

Air bersih hasil pengolahan instalasi pengolahan air wilayah Bojong Renged masih mengandung amoniak $\left(\mathrm{NH}_{4}-\mathrm{N}\right)$ dengan konsentrasi $0,7 \mathrm{mg} / \mathrm{l}$ sehingga tidak memenuhi persyaratan kualitas air bersih ${ }^{(5)}$. Ditinjau dari kualitas air hasil olahan tersebut, instalasi pengolahan air yang dimiliki PDAM tidak efektif untuk menyisihkan amoniak.

\subsection{Pembiakan Mikroorganisma}

Pembiakan (seeding) mikroorganisma dilakukan secara alami yaitu dengan cara mengalirkan air baku secara terus menerus ke dalam reaktor biofilter sampai terbentuknya lapisan biofilm yang melekat pada media biofilter dengan WTH 6 dan 8 jam. Proses pertumbuhan mikroorganisma ini didukung suplai udara 30 liter/menit secara terus menerus. Air baku kontak dengan mikroorganisma yang tersuspensi di dalam air maupun yang menempel pada permukaan media sehingga terjadi penguraian senyawa organik Pembiakan mikroba dilakukan dua tahap, tahap pertama dilakukan pengamatan secara visual tanpa analisa laboratorium, dimana pada tahap awal proses pengolahan ini belum berjalan dengan baik karena mikroorganisma belum tumbuh optimal. Setelah proses berjalan ke tahap dua yaitu mulai ada indikasi mikroba tumbuh yang ditandai dengan terbentuknya lapisan lendir (biofilm) pada permukaan media, mulai dilakukan analisa laboratorium. Lapisan biofilm ini mengandung mikroorganisma pengurai senyawa organik dalam air baku. Pertumbuhan mikroorganisma diamati dengan mengukur penyisihan senyawa organik di dalam bioreaktor setelah 7 hari proses sampai penyisihan senyawa organik stabil (steady state).

Efisiensi penyisihan organik pada awal pengoperasian masih rendah yaitu $29 \%$, hal ini disebabkan pertumbuhan mikroorganisma belum baik yang ditandai dengan biofilm yang terbentuk masih tipis. Minggu kedua efisiensi mulai meningkat menjadi $40 \%$ dan minggu ketiga mencapai $69 \%$. Proses pengolahan pada akhir minggu ketiga telah mencapai kesetabilan, selanjutnya WTH diturunkan menjadi 6 jam. Perubahan WTH dari 8 jam menjadi 6 jam mengakibatkan laju alir meningkat dari 5,25 menjadi 7 liter/menit. Peningkatan laju alir air baku mengakibatkan waktu kontak air baku dengan lapisan biofilm menurun dan diikuti dengan kenaikan laju pembebanan senyawa 
organik, sehingga mengakibatkan efisiensi menurun. Setelah reaktor lima hari beroperasi dengan WTH 6 jam efisiensi sudah mulai menunjukkan kestabilan. Fase ini disebut pematangan dan setelah mencapai kondisi stabil disimpulkan mikroorganisma pengurai telah tumbuh dan bekerja dengan baik(19).

Efisiensi rata-rata penyisihan organik dengan WTH 6 jam sebesar 77\% dan untuk mendapatkan WTH serta efisiensi penyisihan terbaik dilanjutkan dengan penurunan WTH menjadi 4 jam. Penyisihan organik pada saat seeding dapat dilihat pada Gambar 6.

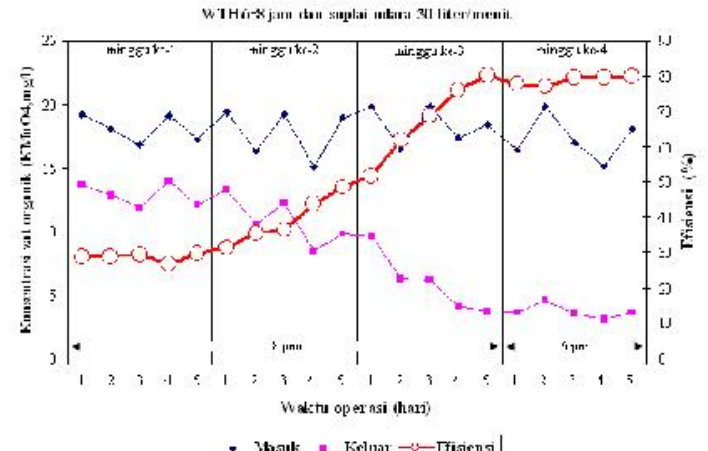

Gambar 6. Penyisihan organik $\left(\mathrm{KMnO}_{4}\right)$ selama proses seeding.

\subsection{Pengaruh WTH Terhadap Penyisihan Amoniak $\left(\mathrm{NH}_{4}-\mathrm{N}\right)$}

Penurunan efisiensi penyisihan senyawa amoniak sebanding dengan penurunan WTH. Penurunan konsentrasi amoniak dalam biofiter menunjukkan terjadinya proses penguraian amoniak pada saat nitrifikasi. Penguraian amoniak pada saat nitrifikasi dilakukan oleh mikroorganisma autotrop maupun heterotrop untuk mensintesa sel. Seperti ditunjukkan pada Gambar 7, efisiensi penyisihan amoniak pada WTH 1-4 jam sebesar 44\%, 65\%, 68\%, dan $71 \%$.

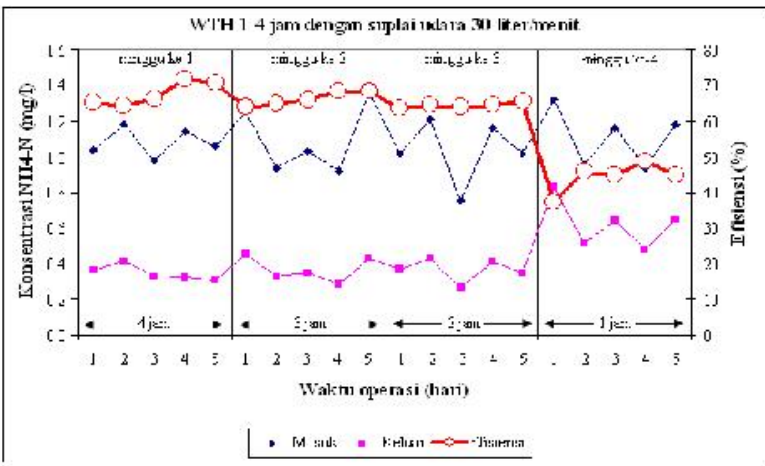

Gambar 7. Penyisihan amoniak (WTH 1-4 jam).

Gambar di atas memperlihatkan efisiensi penyisihan amoniak menurun seiring dengan berkurangnya WTH di dalam reaktor. Hal ini disebabkan berkurangnya waktu kontak antara air baku dengan lapisan biomassa yang tumbuh di media, akibatnya amoniak yang terurai semakin kecil. Efisiensi penyisihan rata-rata tertinggi didapat pada pengkondisian WTH 4 jam yaitu sebesar $71 \%$ dan terendah saat WTH 1 jam sebesar 44\%. Efisiensi penyisihan amoniak pada WTH antara 2 sampai 4 jam masih tergolong tinggi, hal ini disebabkan waktu kontak antara mikroba dengan air baku dan oksigen terlarut masih mencukupi untuk kebutuhan mikroba melakukan sintesa. Pada saat terjadinya penyisihan konsentrasi amoniak di dalam air, terjadi peningkatan konsentrasi nitrat. Perubahan konsentrasi nitrat sebelum dan sesudah pengolahan ditujukkan seperti pada gambar 8 .

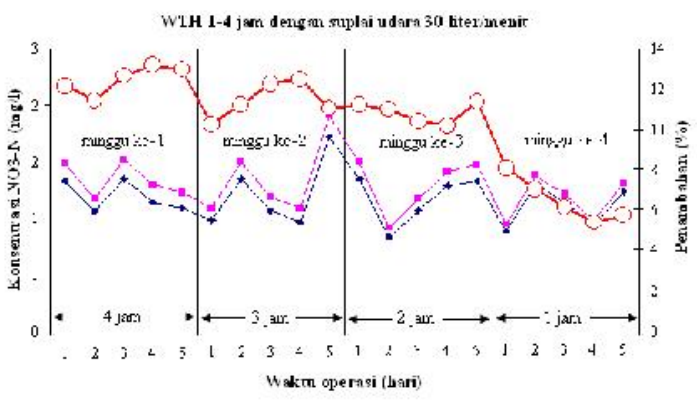

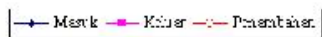

Gambar 8. Peningkatan konsentrasi nitrat $\left(\mathrm{NO}_{3}-\mathrm{N}\right)$ pada WTH 1-4 jam.

Peningkatan konsentrasi nitrat $\left(\mathrm{NO}_{3}-\mathrm{N}\right)$ dapat disebabkan adanya suplai oksigen ke dalam reaktor, dengan reaksi seperti dibawah ini $\begin{array}{lll}\mathrm{NO}_{2}^{-}+1 / 2 \mathrm{O}_{2} & \rightarrow & \mathrm{NO}_{3}^{--} \\ \mathrm{NH}_{4}^{+}+2 \mathrm{O}_{2} & \rightarrow & \mathrm{NO}_{3}^{--}+2 \mathrm{H}^{+}+\mathrm{H}_{2} \mathrm{O}\end{array}$

Senyawa nitrit merupakan senyawa peralihan dalam siklus biologi. Senyawa ini dihasilkan dari suatu proses oksidasi $\mathrm{NH}_{4}-\mathrm{N}$, tetapi sifatnya tidak stabil karena pada kondisi aerobik selama nitrit terbentuk, dengan cepat nitrit dioksidasi menjadi nitrat oleh bakteri nitrobacter, oleh karena itu senyawa nitrit ditemukan dalam jumlah yang kecil. Perubahan konsentrasi nitrit sebelum dan sesudah pengolahan ditunjukkan seperti pada gambar 9 .

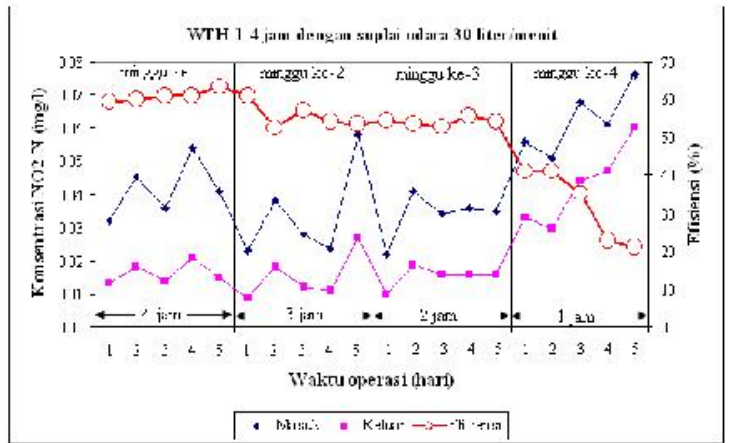

Gambar 9. Penyisihan nitrit $\left(\mathrm{NO}_{2}-\mathrm{N}\right)$ pada WTH 1-4 jam. 


\subsection{Laju Pembebanan Amoniak $\left(\mathrm{NH}_{4}-\mathrm{N}\right)$}

Terjadinya penurunan efisiensi amoniak adalah akibat dari penurunan WTH, sehingga laju pembebanan amoniak semakin besar. Penurunan WTH diikuti oleh penurunan efisiensi penyisihan, peningkatan debit air baku dan laju pembebanan amoniak. Penurunan WTH mengakibatkan debit air baku meningkat sehingga beban hidrolis juga meningkat, sebagai akibatnya efisiensi penyisihan amoniak mengalami penurunan. Laju pembebanan amoniak dalam reaktor biofilter bermedia plastik tipe sarang tawon dengan luas permukaan 226 $\mathrm{m}^{2} / \mathrm{m}^{3}$ pada WTH 1-4 jam adalah $0,4,0,2,0,1$, dan $0,1 \mathrm{~g} / \mathrm{m}^{2}$ media.hari, sedangkan efisiensi penyisihan adalah $47 \%, 65 \%$, 68\%, dan $71 \%$.

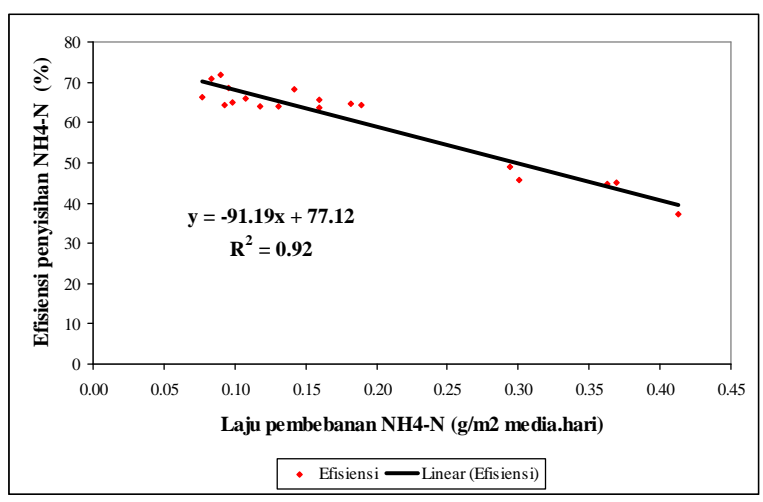

Gambar 10. Laju pembebanan dengan efisiensi penyisihan amoniak.

Gambar 10 di atas menunjukkan hubungan linear antara laju pembebanan dengan efisiensi penyisihan amoniak, dengan persamaan sebagai berikut:

$y_{a}=-91.19 x_{a}+77.12$ dengan $R^{2}=0.92$

dimana

$\mathrm{y}_{\mathrm{a}}=$ Efisiensi penyisihan amoniak, $\mathrm{NH}_{4}-\mathrm{N}(\%)$

$\mathrm{x}_{\mathrm{a}}=$ Laju pembebanan amoniak, $\mathrm{NH}_{4}-\mathrm{N}\left(\mathrm{g} / \mathrm{m}^{2}\right.$ media/hari)

Persamaan tersebut menunjukkan, bahwa pengoperasian reaktor biofilter bermedia plastik tipe sarang tawon yang mempunyai luas permukaan spesifik $226 \mathrm{~m}^{2} / \mathrm{m}^{3}$ dengan laju pembebanan amoniak sebesar 0.08-0.4 $\mathrm{g} / \mathrm{m}^{2}$ media/hari menghasilkan efisiensi penyisihan amoniak sebesar $41-70 \%$.

\subsection{Penentuan WTH Tepilih}

WTH terpilih ditentukan melalui seleksi nilai efisiensi penyisihan senyawa amoniak, dengan mempertimbangkan teknis perencanaan, kelayakan dan aplikasi teknologi biofilter. Waktu tinggal hidrolis yang dipilih adalah WTH tersingkat namun efisiensi penyisihan tinggi.
Efisiensi penyisihan amoniak rata-rata pada WTH 4 jam sebesar $67 \%$. Efisiensi penyisihan ratarata amoniak dapat dilihat pada Tabel 3 .

Tabel 3. Rata-rata efisiensi penyisihan amoniak pada WTH 1-4 jam.

\begin{tabular}{|c|c|}
\hline WTH (jam) & $\begin{array}{c}\text { Rata-rata efisiensi penyisihan } \\
\left.\text { Amoniak [ } \mathbf{N H}_{4}-\mathbf{N}\right](\%)\end{array}$ \\
\hline 1 & 44 \\
\hline 2 & 65 \\
\hline 3 & 68 \\
\hline 4 & 71 \\
\hline
\end{tabular}

Beberapa hal penting yang perlu diperhatikan di dalam teknis perencanaan dan aplikasi reaktor biofilter, antara lain:

- Waktu tinggal hidrolis dalam reaktor singkat

- Efisiensi penyisihan polutan tinggi

- Ukuran lahan yang dipakai kecil

- Bentuk rancangan fleksibel

- Biaya investasi dan operasional rendah

- Air hasil olahan memenuhi kriteria mutu air Golongan I (11).

Ukuran, bobot reaktor, efisiensi penyisihan dan kebutuhan energi merupakan faktor penting dalam perencanaan pembangunan instalasi pengolahan air. Ukuran reaktor menjadi acuan dalam penyediaan lahan, sedangkan bobot reaktor menjadi pertimbangan konstruksi, dimana semakin kecil WTH, ukuran reaktor semakin hemat dalam penggunaan lahan dan dengan bobot reaktor yang lebih kecil memerlukan konstruksi yang lebih ringan. Reaktor dengan efisiensi tinggi mempunyai kemampuan yang lebih besar dalam mengolah air sehingga lebih efisien dalam pemakaian energi untuk peralatan pendukung seperti pompa dan blower. Kualitas air hasil pengolahan juga merupakan faktor yang penting di dalam penentuan pemilihan waktu tinggal hidrolis. Kualitas air baku dan hasil pengolahan proses biofiltrasi pada WTH 1-4 jam dapat dilihat pada Tabel 4.

Tabel 4: Kualitas air baku dan hasil pengolahan pada WTH 1-4 jam.

\begin{tabular}{|c|c|c|c|c|}
\hline \multirow{2}{*}{$\begin{array}{c}\text { WTH } \\
\text { (jam) }\end{array}$} & \multicolumn{4}{|c|}{$\begin{array}{c}\text { Konsentrasi rata-rata amoniak } \\
\text { (mg/liter) }\end{array}$} \\
\cline { 2 - 5 } & \multicolumn{3}{|c|}{ Masuk } & \multicolumn{2}{c|}{ Keluar } \\
\hline 1 & 1.11 & $\mathrm{X}$ & 0.60 & $\mathrm{~V}$ \\
\hline 2 & 1.03 & $\mathrm{X}$ & 0.39 & $\mathrm{~V}$ \\
\hline 3 & 1.10 & $\mathrm{X}$ & 0.37 & $\mathrm{~V}$ \\
\hline 4 & 1.08 & $\mathrm{X}$ & 0.33 & $\mathrm{~V}$ \\
\hline
\end{tabular}

Keterangan:

$\mathrm{x}=$ Tidak memenuhi mutu air golongan I PPRI No. 82/2001 $\mathrm{v}=$ Memenuhi kriteria mutu air golongan I PPRI No. 82/2001

Waktu tinggal hidrolis 2 jam diambil sebagai WTH terpilih, dimana WTH 2 jam adalah WTH terpendek dengan efisiensi penyisihan 
amoniak relatif tinggi. Pertimbangan lain adalah air hasil pengolahan memenuhi kriteria mutu golongan I, yaitu air yang dapat digunakan sebagai air baku air minum(11).

\subsection{Pengaruh Suplai Udara Penyisihan Amoniak $\left(\mathrm{NH}_{4}-\mathrm{N}\right)$}

Terhadap

Efisiensi penyisihan amoniak dengan WTH 2 jam dan variasi suplai udara 0-30 liter/menit ditunjukkan pada Gambar 11. Penurunan konsentrasi amoniak diikuti dengan peningkatan konsentrasi nitrat, hal ini menunjukkan bahwa di dalam reaktor biofilter telah terjadi proses nitrifikasi. Mikroba yang terlibat dalam proses ini adalah bakteri autotrop yang berperan dalam proses nitrifikasi, sedangkan bakteri heterotrop berperan dalam penguraian beban organik. Walaupun bakteri autotrop berperan dalam proses nitrifikasi, proses ini dapat juga terjadi dengan adanya bakteri heterotrop.

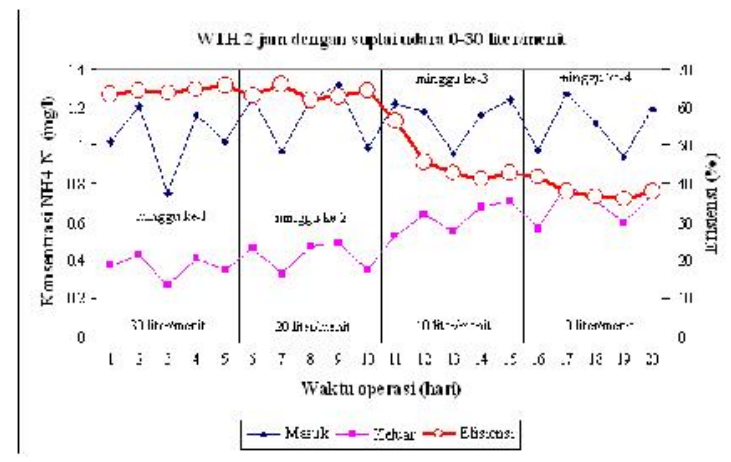

Gambar 11. Penyisihan amoniak pada WTH 2 jam dan suplai udara 0-30 liter/menit.

Pengolahan dengan pengkondisian WTH dari 2 jam dan suplai udara 0-30 liter/menit menghasilkan efisiensi penyisihan rata-rata berturut-turut sebesar 37\%, 43\%, 65\% dan 65\%. Penurunan konsentrasi amoniak pada air olahan menunjukkan terjadinya proses penguraian amoniak pada saat nitrifikasi di dalam reaktor biofilter. Penguraian amoniak pada proses nitrifikasi dilakukan oleh mikroorganisma autotrop maupun heterotrop dalam mensintesa sel.

Identifikasi mikroorganisma yang terdapat dalam biofilm, terdapat bakteri nitrosomonas dan nitrobacter (Laboratorium FKH IPB, 2010). Nitrifikasi merupakan proses pengubahan $\mathrm{NH}_{4}-\mathrm{N}$ menjadi $\mathrm{NO}_{2}-\mathrm{N}$ yang kemudian menjadi $\mathrm{NO}_{3}-\mathrm{N}$ yang dilakukan oleh bakteri autotropik dan heterotropik. Pengubahan $\mathrm{NH}_{4}-\mathrm{N}$ menjadi $\mathrm{NO}_{2}-\mathrm{N}$ dilakukan oleh bakteri nitrosomonas dan selanjutnya $\mathrm{NO}_{2}-\mathrm{N}$ yang terbentuk diubah menjadi $\mathrm{NO}_{3}-\mathrm{N}$ oleh bakteri nitrobacter. Kedua jenis bakteri di atas berlangsung dalam keadaan aerob sehingga memerlukan konsentrasi oksigen yang cukup untuk sumber energi dalam menunjang proses metabolisme, dan juga proses nitrifikasi merupakan suatu proses aerob sehingga keberadaan oksigen sangat penting dalam proses ini. Konsentrasi oksigen terlarut yang diperlukan agar proses nitrifikasi dapat berjalan dengan baik, yaitu jika DO minimumnya $>1 \mathrm{mg} / \mathrm{l}$, tetapi bila konsentrasi DO di bawah 1 $\mathrm{mg} / \mathrm{l}$ maka proses nitrifikasi menjadi lambat.

Fungsi suplai udara pada reaktor biofilter adalah mensuplai oksigen untuk mendukung mikroorganisma melakukan penguraian polutan dalam air baku dan digunakan untuk menjaga kestabilan biofilm dari gangguan material yang menghalangi lapisan biomassa dan merontokkan biofilm yang telah mati. Perubahan suplai udara dari 20 menjadi 10 dan 0 liter/menit mengakibatkan efisiensi penyisihan senyawa organik turun dengan efisiensi rata-rata penyisihan $43 \%$ dan $37 \%$. DO yang terukur pada titik masuk sekitar $5,5 \mathrm{mg} / \mathrm{l}$ dan pada titik keluar sekitar $3 \mathrm{mg} / \mathrm{l}$. Syarat DO yang diperlukan dalam proses biofiltrasi mencukupi mikroorganisma untuk melakukan penguraian senyawa amoniak, walaupun mendekati syarat minimal. Suhu operasi reaktor biofilter antara 28,2-28,7 dan $\mathrm{pH}$ antara 7,1-7,5 adalah kondisi yang baik untuk mikroorganisma melakukan penguraian.

Inhibitor maupun toksik tidak teridentifikasi di dalam sistem, faktor penghambat yang menghalangi lapisan biofilm kontak dengan air baku kemungkinan bisa terjadi dari pengendapan tanah, lempung dan pasir halus yang menutupi sebagian lapisan biomassa. Lempung dan tanah halus yang tersuspensi di dalam air baku. Penurunan efisiensi penyisihan senyawa amoniak di dalam reaktor biofilter pada variasi suplai udara 0-10 liter/menit dapat dikatakan akibat tertutupnya biofilm oleh tanah halus dan lempung, sehingga luas kontak antara biofilm dengan air baku berkurang dan mikrooganisma tidak mendapatkan suplai oksigen dan makanan yang mencukupi.

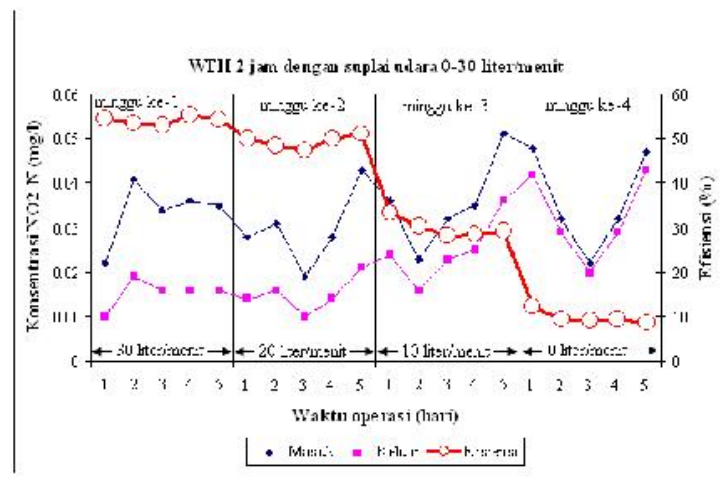

Gambar 12. Penyisihan $\mathrm{NO}_{2}-\mathrm{N}$ pada WTH 2 jam dan suplai udara 0-30 l/min.

Penurunan konsentrasi amoniak $\left(\mathrm{NH}_{4}-\mathrm{N}\right)$ diikuti dengan penurunan nitrit $\left(\mathrm{NO}_{2}-\mathrm{N}\right)$ dan peningkatan konsentrasi nitrat ( $\left.\mathrm{NO}_{3}-\mathrm{N}\right)$. 
Perubahan konsentrasi $\left(\mathrm{NO}_{2}-\mathrm{N}\right) \quad\left(\mathrm{NO}_{3}-\mathrm{N}\right)$ pada saat penurunan konsentrai $\mathrm{NH}_{4}-\mathrm{N}$ dapat dilihat pada Gambar 12 di atas dan Gambar 13. Senyawa nitrit merupakan senyawa peralihan dalam siklus biologi. Senyawa ini dihasilkan dari proses oksidasi $\mathrm{NH}_{4}-\mathrm{N}$, tetapi sifatnya tidak stabil karena pada kondisi aerobik selama nitrit terbentuk, dengan cepat nitrit dioksidasi menjadi nitrat oleh bakteri nitrobacter, oleh karena itu senyawa nitrit ditemukan dalam jumlah yang kecil. Peningkatan konsentrasi $\mathrm{NO}_{3}-\mathrm{N}$ dapat disebabkan adanya oksigen yang dialiri secara terus menerus ke dalam reaktor, sehingga dapat menyebabkan pembentukan nitrat, seperti reaksi di bawah ini :

$$
\begin{aligned}
& \mathrm{NO}_{2}^{-}+1 / 2 \mathrm{O}_{2} \rightarrow \mathrm{NO}_{3}^{--} \\
& \mathrm{NH}_{4}^{+}+2 \mathrm{O}_{2} \rightarrow \mathrm{NO}_{3}^{--}+2 \mathrm{H}^{+}+\mathrm{H}_{2} \mathrm{O}
\end{aligned}
$$

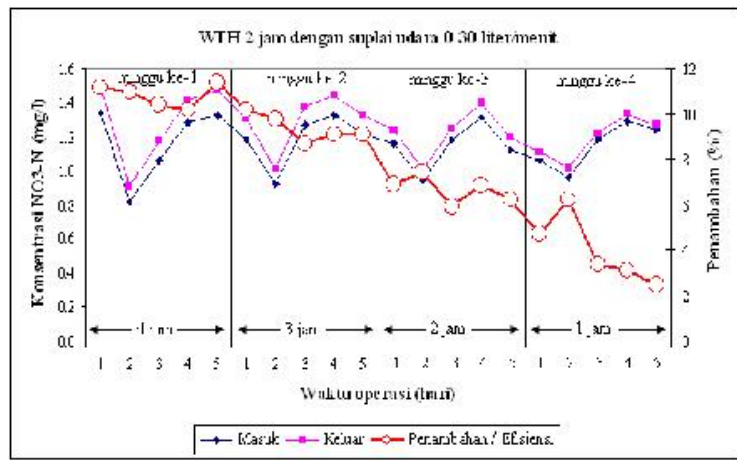

Gambar 13. Peningkatan konsentrasi $\mathrm{NO}_{3}-\mathrm{N}$ pada WTH 2 jam dan suplai udara 0-30 liter/menit.

$\mathrm{pH}$ optimum untuk aktivitas bakteri nitrosomonas dan nitrobacter agar dapat berjalan dengan optimal, yaitu antara $7,5-8,5$. Kondisi operasi reaktor biofilter dengan $\mathrm{pH}$ antara 7,0 7,5 menyebabkan peran bakteri nitrosomonas dalam proses nitrifikasi belum berjalan secara optimal, begitu pula dengan bakteri nitrobacter yang mengubah nitrit menjadi nitrat. Berdasarkan pernyataan tersebut efisiensi penyisihan yang rendah pada WTH 2 jam dan suplai udara 0-10 liter/menit, selain dari gangguan tertutupnya lapisan biofilm oleh tanah halus, dapat juga disebabkan bakteri nitrosomonas dan nitrobacter tidak bekerja maksimal(12).

Bahan organik merupakan salah satu faktor yang dapat mempengaruhi banyak atau sedikitnya konsentrasi amonium yang terjadi dalam proses nitrifikasi. Pada air buangan, $60 \%$ nitrogen mengandung bahan organik, $40 \%$ nitrogen berada dalam bentuk amoniak, dan < $1 \%$ berada dalam bentuk nitrit dan nitrat. Bakteri heterotrop menggunakan substrat organik sebagai sumber energinya, sedangkan bakteri autotrof menggunakan senyawa $\mathrm{CO}_{2}$ dan $\mathrm{HCO}_{3}$ sebagai sumber energi yang diperoleh dari hasil oksidasi bakteri heterotrop, maka dapat dikatakan bahwa efisiensi penyisihan pada proses nitrifikasi sejalan dengan proses penyisihan organik.

\subsection{Penentuan Suplai Udara Terpilih}

Seperti telah dijelaskan di atas beberapa hal penting yang perlu diperhatikan di dalam teknis perencanaan dan kelayakan aplikasi reaktor biofilter, antara lain:

- Waktu tinggal hidrolis dalam reaktor singkat

- Efisiensi penyisihan polutan tinggi

- Ukuran lahan yang dipakai kecil

- Bentuk rancangan fleksibel

- Biaya investasi dan operasional rendah

- Air hasil olahan memenuhi kriteria mutu Golongan I (11)

Luas lahan yang dibutuhkan untuk instalasi, ukuran dan bobot reaktor, serta waktu tinggal, efisiensi penyisihan dan kebutuhan energi merupakan faktor penting dalam pembangunan fisik instalasi pengolahan air. Ukuran reaktor menjadi penentu dalam luas lahan yang dibutuhkan, sedangkan bobot reaktor menjadi pertimbangan kemudahan dan efisiensi konstruksi. WTH mempengaruhi dimensi reaktor, semakin kecil WTH dimensi reaktor semakin kecil. Dimensi reaktor biofilter yang ringkas akan menghemat dalam penggunaan lahan, bobot lebih ringan dan konstruksi lebih murah. Reaktor dengan efisiensi tinggi mempunyai kemampuan yang lebih besar dalam mengolah air, sehingga lebih efisien dalam pemakaian energi untuk peralatan pendukung seperti pompa, blower dan peralatan pendukung lainnya. Kualitas air hasil pengolahan juga merupakan faktor yang penting di dalam pertimbangan pemilihan jumlah suplai udara. Kualitas air baku dan hasil pengolahan dari proses biofiltrasi pada WTH 2 jam dan suplai udara 0-30 liter/menit dapat dilihat pada Tabel 5.

Tabel 5. Kualitas air baku dan hasil pengolahan pada WTH 2 jam dan suplai udara 0-30 liter/menit.

\begin{tabular}{|c|c|c|c|c|}
\hline \multirow{2}{*}{ WTH (jam) } & \multicolumn{4}{|c|}{$\begin{array}{c}\text { Konsentrasi rata-rata amoniak } \\
\text { (mg/liter) }\end{array}$} \\
\cline { 2 - 5 } & \multicolumn{2}{|c|}{ Masuk } & \multicolumn{2}{c|}{ Keluar } \\
\hline 0 & 1.10 & $\mathrm{X}$ & 0.68 & $\mathrm{X}$ \\
\hline 10 & 1.15 & $\mathrm{X}$ & 0.62 & $\mathrm{X}$ \\
\hline 20 & 1.15 & $\mathrm{X}$ & 0.42 & $\mathrm{~V}$ \\
\hline 30 & 1.03 & $\mathrm{X}$ & 0.37 & $\mathrm{~V}$ \\
\hline
\end{tabular}

Keterangan:

$\mathrm{x}=$ Tidak memenuhi mutu air golongan I PPRI No. 82/2001 $\mathrm{v}=$ Memenuhi mutu air golongan I PPRI No. 82/2001

WTH 2 jam dan suplai udara 20 liter/menit diambil sebagai suplai udara terpilih, dimana pada suplai udara 20 liter/menit merupakan 
suplai udara terbaik dengan efisiensi penyisihan tergolong tinggi untuk mereduksi amoniak dan air hasil pengolahan memenuhi kriteria mutu golongan I (11).

\subsection{Identifikasi Mikroorganisma}

Di dalam proses pengolahan air secara biologis, mikroorganisma merupakan faktor yang penting terhadap berlangsungnya proses biologis baik dalam penyisihan kandungan bahan organik maupun dalam proses nitrifikasi. Identifikasi mikroorganisma pada reaktor biofilter dengan media biakan tipe sarang tawon ini bertujuan untuk mengetahui jenis mikroorganisma yang berperan dalam penyisihan amoniak. Hasil identifikasi mikroorganisme yang terdapat di dalam reaktor biofilter dengan media biakan tipe sarang tawon adalah basilus subtilis, proteus sp, nitrosomonas sp, nitrobacter sp, escherichia coli dan clostridium sp (Laboratorium FKH IPB 2010) Bakteri basilus subtilis, closttridium dan Proteus sp adalah diidentifikasi sebagai pengurai senyawa organik, sedangkan pengurai amoniak adalah nitrosomonas dan nitrobacter. .

\section{KESIMPULAN DAN SARAN}

\subsection{Kesimpulan}

- WTH semakin pendek laju pembebanan semakin besar dan efisiensi penyisihan amonia semakin kecil.

- Kondisi operasi terpilih pada WTH 2 jam dan suplai udara 20 liter/menit dengan efisiensi penyisihkan amoniak $65 \%$.

- Pengolahan air baku PAM dengan penerapan proses biofiltrasi dengan media plastik tipe sarang tawon menghasilkan air olahan memenuhi kriteria mutu air golongan I sebagai air baku PAM (11).

- Rekomendasi disain reaktor biofilter :

Suhu operasi $(\mathrm{T})=28-30^{\circ} \mathrm{C}$

Tekanan operasi $(\mathrm{P})=1 \mathrm{~atm}$

pH operasi $(\mathrm{pH})=6,8-7,5$

Media biofilter:

$\begin{array}{ll}\text { Bahan } & =\text { Plastik } \\ \text { Tipe } & =\text { Sarang tawon } \\ \text { WTH } & =2 \text { jam }\end{array}$

Suplai udara terpilih $(\mathrm{Qu})$

$=0,1035 \mathrm{Ipm} / \mathrm{m}^{2}$ media

Laju pembebanan amoniak $\left(\mathrm{NH}_{4}-\mathrm{N}\right)$ (La)

$=0,2 \mathrm{~g} / \mathrm{m}^{2}$ media.hari

- Persamaan regresi laju pembebanan dan efisiensi penyisihan amoniak :

$y_{a}=-91,19 x_{a}+77,12 \quad\left(R^{2}=0,92\right)$

\subsection{Saran}

- $\quad$ Suplai udara berpengaruh terhadap efisiensi penyisihan amoniak sehingga perlu penerapan difuser udara dengan ukuran yang lebih halus untuk memperluas kontak antara air baku dengan udara.

- Penyisihan amoniak juga berlangsung pada kondisi tanpa suplai udara, untuk meningkatkan efisiensi penyisihan zat tersebut perlu mengkombinasikan proses biofiltrasi secara aerobik dengan anaerobik.

- Perlu dilakukan penyempurnaan proses pengendapan awal, untuk mengurangi padatan tersuspensi yang dapat mengganggu kontak antara lapisan biofilm dengan air baku. 


\section{DAFTAR PUSTAKA}

1. Barnes, D., and P.J. Blisse. 1980. Biological Control of Nitrogen In Wastewater Treatment. London. New York.

2. Bitton, G. 1994. Wastewater Microbiology. Willey-Liss. New York.

3. Grady, C.P.L., and H.C. Lim. 1980. Biological Wastewater Treatment: Theory\& Application. Marcell Dekker.Inc. New York.

4. Jennings, J.R. 1991. Catalytic Ammonia Syntesis:Fundamentals and Practice. Plenum Press. New York.

5. Keputusan Menteri Kesehatan Repuplik Indonesia Nomor 907/MENKES/SK/VII/2002 tanggal 29 Juli 2002 tentang syarat-syarat dan pengawasan kualitas air minum.

6. Lyssenko, C and F. Wheaton.2006. Impact of positive ramp short-term operating disturbances on ammonia removal by trickling and submerged-upflow biofilters for intensive recirculating aquaculture. Aquacultural Engineering 35: 36-37.

7. Manahan, S.E. 1994. Environmental Chemistry. $6^{\text {th }}$ edition. Lewis Publishers. Tokyo.

8. Metcalf and Eddy. 2003. Wastewater Engineering: Treatment and Reuse. $4^{\text {th }}$. Mc Graw Hill.Singapore.
9. PDAM Tirta Kerta Raharja Kabupaten Tangerang. 2000. Panduan Analisa KimiaFisika. Perusahaan Daerah Air Minum Kabupaten Tangerang. Tangerang.

10. Pelezar, M.J., dan E.C.S. Chan. 1996. Dasar-dasar Mikrobiologi. UI Press, Jakarta.

11. Peraturan Pemerintah Republik Indonesia (PPRI) No. 82 Tahun 2001. tentang Pengelolaan Kualitas Air dan Pengendalian Pencemaran Lingkungan. Jakarta.

12. Rosa, M.F., A.A.L. Furtado, R.T. Albuquerque, S.G.F. Leite, and R.A. Medronho.1998. Biofilm development and ammonia removal in nitrification a saline wastewater. Bioresource Technology 65: 135-138.

13. Watten, B.J., and P.L.,Sibrell. 2006. Comparative performance of fixed-film biological filters: Application of reactor theory. Aquacultural Engineering 34: 198213

14. Winkler, M.A. 1981. Biological Treatment of Wastewater. John Willey and Sons. New York. 